\title{
Genome-wide ChIPseq analysis of AhR, COUP-TF, and HNF4 enrichment in TCDD-treated mouse liver
}

Giovan N. Cholico, Rance Nault, Timothy R. Zacharewski*

Biochemistry \& Molecular Biology, Institute for Integrative Toxicology, Michigan State University, East Lansing, MI 48824

${ }^{*}$ Correspondence:

Tim Zacharewski

Michigan State University

Department of Biochemistry \& Molecular Biology

Biochemistry Building

603 Wilson Road

East Lansing, MI 48824

tzachare@msu.edu 


\section{ABSTRACT}

The aryl hydrocarbon receptor $(\mathrm{AhR})$ is a ligand-activated transcription factor known for mediating the toxicity of 2,3,7,8-tetrachlorodibenzo-p-dioxin (TCDD) and related compounds. Although the canonical mechanism of AhR activation involves heterodimerization with the aryl hydrocarbon receptor nuclear translocator, other transcriptional regulators that interact with AhR have been identified. Enrichment analysis of motifs in AhRbound genomic regions implicated co-operation with COUP transcription factor (COUP-TF) and hepatocyte nuclear factor 4 (HNF4). The present study investigated AhR, HNF4a and COUP-TFII genomic binding and effects on gene expression associated with liver-specific function and cell differentiation in response to TCDD. Hepatic ChIPseq data from male C57BL/6 mice at $2 \mathrm{hrs}$ after oral gavage with $30 \mu \mathrm{g} / \mathrm{kg}$ TCDD were integrated with bulk RNA-sequencing (RNAseq) time-course (2 - $72 \mathrm{hrs)}$ and dose-response $(0.01-30 \mu \mathrm{g} / \mathrm{kg})$ datasets to assess putative AhR, HNF4a and COUP-TFII interactions associated with differential gene expression. TCDD treatment resulted in the genomic enrichment of 23,701, 11,688, and 9,547 binding regions for AhR, COUPTFII and HNF4a, respectively, throughout the genome. Functional enrichment analysis of differentially expressed genes (DEGs) identified differential binding enrichment for AhR, COUP-TFII, and HNF4a to regions within liver-specific genes suggesting intersections associated with the loss of liver-specific functions and hepatocyte differentiation. Analysis found that the repression of liver-specific, HNF4a target and hepatocyte differentiation genes, involved increased AhR and HNF4a binding with decreased COUP-TFII binding. Collectively, these results suggested TCDD-elicited loss of liver-specific functions and markers of hepatocyte differentiation involved interactions between AhR, COUP-TFII and HNF4a. 
bioRxiv preprint doi: https://doi.org/10.1101/2021.06.18.448955; this version posted June 18, 2021. The copyright holder for this preprint (which was not certified by peer review) is the author/funder, who has granted bioRxiv a license to display the preprint in perpetuity. It is made available under aCC-BY-NC-ND 4.0 International license.

\section{INTRODUCTION}

The aryl hydrocarbon receptor $(\mathrm{AhR})$ is a ligand-activated transcription factor that belongs to the Per-Arnt-Sim basic-helix-loop-helix (PAS-bHLH) superfamily of proteins. When inactive, cytosolic AhR resides in the cytosol interacting with HSP90, AIP, p23 and SRC chaperone proteins (Rothhammer and Quintana, 2019). Following ligand binding, the chaperone proteins are shed and the AhR translocates into the nucleus. Canonical activation involves heterodimerization with the AhR nuclear translocator protein (ARNT) with subsequent binding to dioxin response elements (DREs) to elicit gene transcription (Rothhammer and Quintana, 2019). However, not all differentially expressed genes (DEGs) possess DREs, and studies have shown the AhR can bind to non-consensus DNA motifs to regulate gene expression (Denison et al., 2011; Dere et al., 2011). Moreover, the $A h R$ can also interact with other transcription factors including the estrogen receptor $(E R-\alpha / \beta)$ (Ohtake et al., 2003), retinoic acid receptor (RAR) (Murphy et al., 2004), and Krüppel-like factor 6 (KLF6) (Wilson et al., 2013).

Although its endogenous function has yet to be resolved, numerous structurally diverse endogenous metabolites, natural products, and microbial compounds bind and activate the AhR (Larigot et al., 2018). The AhR also mediates effects in response to polycyclic aromatic hydrocarbons (PAHs), polychlorinated dibenzo- $p$ dioxins (PCDDs), dibenzofurans (PCDFs), and biphenyls (PCBs) (Larigot et al., 2018). 2,3,7,8Tetrachlorodibenzo-p-dioxin (TCDD) is the most potent AhR ligand known to elicit a plethora of adverse effects across a broad spectrum of tissues and species. For example, an acute oral dose of TCDD induces hepatic steatosis with extrahepatic immune cell infiltration (Boverhof et al., 2005), with chronic exposure resulting in the progression of fatty liver to steatohepatitis with fibrosis (Pierre et al., 2014). Although the mechanism of TCDD and related compound toxicity is poorly understood, knockout studies indicate that most, if not all, adverse effects are the result of differential gene expression mediated by the AhR (Fernandez-Salguero et al., 1996).

The AhR has also been implicated in indirectly cooperating with other transcriptional regulators. AhR-bound DNA regions following TCDD treatment in the mouse liver are enriched in binding motifs for hepatocyte nuclear factor 4 (HNF4), COUP transcription factor (COUP-TF), peroxisome proliferator-activated receptor (PPAR), retinoid $X$ receptor $(R X R)$, liver $X$ receptor $(L X R)$, and nuclear factor erythroid 2-related factor 2 (NRF2) (Dere et al., 2011; Nault et al., 2018). These transcription factors regulate hallmark hepatic functions including lipid metabolism, antioxidant responses, and hepatocyte differentiation, all functions dysregulated by TCDD (Angrish et al., 2013, 2012; Cholico et al., 2021; Doskey et al., 2020; Fader et al., 2017b, 2015; Lu et al., 2011; Nault et al., 2018, 2017a, 2017b; Yeager et al., 2009). Moreover, treatment with TCDD every 4 days for 28 days resulted in a loss of liver-specific gene expression leaving a functionally dedifferentiated hepatocyte phenotype (Nault et al., 2017a).

Hepatocyte differentiation is primarily mediated by HNF4a as early as endoderm formation during embryogenesis (Parviz et al., 2003). HNF4a maintains differentiation by regulating hallmark hepatocyte functions such as lipid and bile metabolism, gluconeogenesis, amino acid metabolism, and blood coagulation (Bonzo et al., 2012). HNF4a is a nuclear transcription factor that regulates gene expression as a homodimer 
but can involve more complex interactions such as heterodimerization with COUP-TFs and RXR. Specifically, HNF4a co-interaction with COUP-TFII elicits tissue-specific inhibitory and synergistic gene expression effects (Ashraf et al., 2019). Alternatively, COUP-TFIl dimerizes with RXR and competes with HNF4a/RXR for the same binding site or sequesters RXR thereby limiting HNF4a/RXR signaling events (Ashraf et al., 2019). Considering that COUP-TFs can functionally inhibit HNF4a-signaling in the liver, and that AhR-genomic binding motifs are enriched with HNF4a binding sites, we tested the hypothesis that AhR, HNF4a, and COUPTFII potentially intersect to regulate liver-specific functions and hepatocyte differentiation following TCDD treatment. 
bioRxiv preprint doi: https://doi.org/10.1101/2021.06.18.448955; this version posted June 18, 2021. The copyright holder for this preprint (which was not certified by peer review) is the author/funder, who has granted bioRxiv a license to display the preprint in perpetuity. It is made available under aCC-BY-NC-ND 4.0 International license.

\section{METHODS}

Animal Treatment - Male C57BL/6 mice (Charles River Laboratories, Kingston, NY) were treated as previously described (Nault et al., 2018). Briefly, mice were housed at $23^{\circ} \mathrm{C}$, with $30-40 \%$ humidity, in $12 \mathrm{hr}$ light/dark cycles. Food and water were available to mice ad libitum. TCDD (AccuStandard, New Haven, CT) was dissolved in acetone and diluted in sesame oil to a working stock. Postnatal day 28 mice were weighed and treated with $30 \mu \mathrm{g} / \mathrm{kg}$ TCDD or sesame oil. Mice were asphyxiated with carbon dioxide at 2 hrs posttreatment. The liver tissues were excised and snap frozen in liquid nitrogen. Tissues were then stored at $-80^{\circ} \mathrm{C}$ until ChIP-sequencing (ChIPseq) could be conducted. Five mice were used for each treatment group. Animal studies were conducted with the approval of the Michigan State University Institutional Animal Care and Use Committee (PROTO201800043) and meet ARRIVE guidelines.

ChIP-Sequencing - ChIPseq analysis of COUP-TFII and HNF4a was conducted through Active Motif (Carlsbad, CA). Equal amounts of liver tissue following a $2 \mathrm{hrs} 30 \mu \mathrm{g} / \mathrm{kg}$ TCDD or vehicle exposure from five C57BL/6 male mice ( $100 \mathrm{mg}$ ) were pooled prior to ChIPseq analysis. Previously published ChIPseq data was used to identify AhR genomic binding sites after $2 \mathrm{hrs}$ of $30 \mu \mathrm{g} / \mathrm{kg}$ TCDD exposure in C57BL/6 male mice (Fader et al., 2017b)(GEO: GSE97634). The fold-change for each genomic binding site was determined by comparing peak values from TCDD-treated samples against the vehicle control samples. Peaks with a $0.6 \geq$ fold-change $\geq 1.5$ were considered differentially enriched. The ChIPseq data for COUP-TFII and HNF4a have been deposited on the Gene Expression Omnibus (GEO; GSE178168).

RNA-Sequencing - Previously published time-dependent (Nault et al., 2018) (GEO: GSE109863) and repeated-dose dose-response (Fader et al., 2017a)(GEO: GSE87519), hepatic RNAseq datasets were used to assess transcriptional changes following TCDD exposure in mice. Briefly, for the time-dependent study, mice were exposed to $30 \mu \mathrm{g} / \mathrm{kg}$ TCDD (or vehicle control) for 2, 4, 8, 12, 24, or $72 \mathrm{hrs}$, after which liver tissue was collected and bulk RNAseq was performed. For the repeated-dose dose-response study, mice were exposed to $0.01,0.03,0.1,0.3,1,3,10$, or $30 \mu \mathrm{g} / \mathrm{kg}$ TCDD (or vehicle control) ever 4 days for 28 days, after which liver tissue was collected and bulk RNAseq was performed. For both datasets, gene expression fold-changes were calculated between TCDD-treated and time-matched vehicle-treated mice, along with posterior probabilities $[\mathrm{P} 1(t)]$. Genes were considered differentially expressed with a $0.6 \geq$ fold-change $\geq 1.5$ and $\mathrm{P} 1(t) \geq 0.8$.

Functional and Motif Enrichment Analyses - Functional enrichment was performed using BC3NET (de Matos Simoes and Emmert-Streib, 2012). Gene sets obtained from the gene set knowledgebase (GSKB; http://ge-lab.org/gskb/) were filtered to include only terms from the following databases: SMPDB, GO, KEGG, REACTOME, EHMN, MICROCOSM, MIRTARBASE, MPO, PID, PANTHER, BIOCARTA, INOH, NETPATH, WIKIPATHWAYS, MOUSECYC, TF, TFACTS. The subset GSKB gene sets were then complemented with inhouse derived gene sets. All gene sets that were assessed for functional enrichment can be found at that Harvard Dataverse (https://doi.org/10.7910/DVN/OCKYFO). Protein encoding genes defined in Ensembl GRCm38 (released 102) were used as the reference gene set (Durinck et al., 2009). Analysis of known DNA 
motifs was conducted for differentially enriched regions in each ChIPseq dataset using HOMER v4.11.1 (http://homer.ucsd.edu/homer/motif/). All enriched motifs can be found in the supplementary file.

ChIPseq Transcription Factor Overrepresentation Analysis - Overrepresentation of AhR, COUP-TFII, and HNF4a binding patterns (e.g., increased, decreased, and no change) on subsets of differentially expressed genes (DEGs) was performed using BC3NET. Gene sets were determined by assessing all possible transcription factor binding patterns for intragenic regions within the AhR, COUP-TFII, and HNF4a ChIPseq data. All DEGs in the RNAseq data of mice treated with $30 \mu \mathrm{g} / \mathrm{kg}$ TCDD every 4 days for 28 days were used as the reference gene set.

Gene Set Enrichment Analysis - GSEA (v 4.0.3) was used to perform a gene set enrichment analysis (GSEA) (Subramanian et al., 2005) using a pre-ranked list of genes based on fold-change (induction to repression) for mice treated with $30 \mu \mathrm{g} / \mathrm{kg}$ TCDD every 4 days for 28 days. 
bioRxiv preprint doi: https://doi.org/10.1101/2021.06.18.448955; this version posted June 18, 2021. The copyright holder for this preprint (which was not certified by peer review) is the author/funder, who has granted bioRxiv a license to display the preprint in perpetuity. It is made available under aCC-BY-NC-ND 4.0 International license.

\section{RESULTS}

Evaluation of ChIPseq Datasets - ChIPseq analysis of COUP-TFII and HNF4a identified a total of 30,960 and 43,233 enriched genomic binding locations (Fig. 1). These data were analyzed in combination with published AhR ChIPseq data that reported 27,413 enriched genomic regions following treatment with $30 \mu \mathrm{g} / \mathrm{kg}$ TCDD for 2 hrs (Nault et al., 2016b). Binding was predominantly localized to intragenic (-10Kb of transcription start site to transcription stop site) regions for the AhR (57.4\%), COUP-TFII (81.5\%) and HNF4a (76.4\%). Evaluation of TCDD-elicited changes in genomic binding showed only AhR binding increased (median Log 2 fold-change $=0.99$ ). Only positive $\log _{2}$ fold-changes in genomic AhR enrichment were reported since the AhR is a ligand-activated transcription factor that predominantly resides in the cytosol. In contrast, COUP-TFII (median $\log _{2}$ fold-change $=-0.30$ ) and HNF4a (median $\log _{2}$ fold-change $=0.13$ ) exhibited both increased and decreased binding following treatment with $30 \mu \mathrm{g} / \mathrm{kg}$ TCDD for $2 \mathrm{hrs}$.

Differential AhR, COUP-TFII and HNF4a ChIPseq peak enrichment, characterized by $0.6 \geq$ foldchange $\geq 1.5$, was examined (Fig 2.). Of the 23,713 AhR enriched peaks, 23,701 were defined as enriched (99.9\%). In contrast, 11,688 of the 30,960 (37.8\%) COUP-TFII peaks were enriched, and 9,547 of the 42,233 (22.6\%) HNF4a peaks were enriched. COUP-TFII possessed 2,720 positively (i.e., increased binding) differentially enriched peaks and 8,968 negatively (i.e., reduced binding) differentially enriched peaks. HNF4a possessed 6,224 positively differentially enriched peaks and 3,323 negatively differentially enriched peaks. The sequences for these differentially enriched regions were assessed for over-represented DNA binding motifs. For AhR-enriched sequences, 31.53\% and 13.06\% possessed DNA binding motifs for AhR/Arnt and HNF4a, respectively, as well as COUP-TFII (25.10\%; data not shown). Positively differentially enriched COUP-TFII sequences binding sites contained over-represented COUP-TFII (26.89\% and 30.60\%) and HNF4a (11.15\%) binding motifs, while negatively differentially enriched COUP-TFII sequences possessed two different overrepresented COUP-TFII binding sites (29.03\% and 32.62\%). Similarly, positively differentially enriched HNF4a sequences possessed over-represented HNF4a (7.42\%), COUP-TFII (18.88\% and 21.82\%) and AhR/Arnt $(10.71 \%)$ binding motifs, while negatively differentially enriched HNF4a sequences possessed overrepresented HNF4a binding motifs (30.42\%).

Differentially enriched peaks between the three ChIPseq data sets were evaluated for overlap (Fig. 3). In reference to all differentially enriched AhR peaks, $47.85 \%$ and $70.09 \%$ of these peaks also overlapped with differentially enriched COUP-TFII and HNF4a peaks, respectively. In reference to differentially enriched COUP-TFII peaks, $25.57 \%$ and $72.87 \%$ overlapped with differentially enriched AhR and HNF4a peaks, respectively, while $28.15 \%$ and $53.93 \%$ of all differentially enriched HNF4a peaks overlapped with differentially enriched AhR and COUP-TFII peaks, respectively.

Evaluation of Transcription Factor Gene Targets - Intragenic peaks were further evaluated to identify putative gene targets (Fig. 4). Gene targets harboring binding sites for multiple transcription factors anywhere within the intragenic region (regardless of overlap between transcription factor binding sites) were defined as 
possibly possessing intersections between AhR, COUP-TFII and HNF4a in the present study. Gene targets were assessed for binding of individual transcription factors, the intersection between two of the transcription factors, and the intersection between all three transcription factors. 7,762, 13,377 and 13,744 unique genes were identified as possessing intragenic binding of AhR, COUP-TFII, and HNF4a, respectively. Putative effects of TCDD were determined by associating differentially enriched peaks with the closest gene within the intragenic region, thereby limiting the number of potential targets for AhR, COUP-TFII, and HNF4a to 7,761, 6,846, and 5,762 unique genes, respectively. Potential intersections between transcription factors and subsequent putative gene co-regulation were determined by identifying common genes in which at least one of three transcription factors possessed a differentially enriched peak. It was assumed that a change in binding for only one transcription factor is necessary to elicit differential gene expression. The number of genes showing co-enrichment of AhR and COUP-TFII was 6,687, while 6,954 and 8,080 showed co-enrichment with at least one differentially enriched transcription factor for AhR and HNF4a, or COUP-TFII and HNF4a, respectively. A total of 6,376 genes exhibited co-enrichment with at least one differentially enriched transcription factor for AhR, COUP-TFII and HNF4a.

Evaluation of Gene Transcriptional Changes - ChIPseq and RNAseq data were integrated to identify changes in gene expression for putative co-regulated genes (Fig. 5). Time course RNAseq data, in which mice were treated with $30 \mu \mathrm{g} / \mathrm{kg}$ TCDD and sacrificed 2, 4, 8, 12, 24, and $72 \mathrm{hrs}$ after treatment, were used to assess the acute effects of TCDD on hepatic gene expression. Dose-response RNAseq data were used to assess the sub-chronic hepatic effects of TCDD in mice treated with $0.01,0.03,0.1,0.3,1,3,10$, or $30 \mu \mathrm{g} / \mathrm{kg}$ TCDD every 4 days for 28 days total. Among DEGs enriched for AhR, COUP-TFII, and/or HNF4a that exhibited differential expression $[0.6 \geq$ fold-change $\geq 1.5$ and $\mathrm{P} 1(t) \geq 0.8$ ] following acute exposure, the median fold-change was positive indicating primarily induction (Fig. 5A). Conversely, sub-chronic TCDD treatment elicited mixed differential expression in transcription factor-bound genes. For example, 0.01 to $3 \mu \mathrm{g} / \mathrm{kg}$ induced and repressed the expression of putatively co-regulated genes. In contrast, mice gavaged with $10 \mathrm{or} 30 \mu \mathrm{g} / \mathrm{kg}$ exhibited more repression of putative co-regulated differentially expressed genes (DEGs). Of the 6,376 genes that were putatively co-regulated by AhR, COUP-TFII and HNF4a, 2,680 were differentially expressed (median $\log _{2}$ fold-change $=-0.79$ ) after oral gavage every 4 days for 28 days with TCDD. Of these 2,680 DEGs, 1,106 were induced and 1,574 were repressed (Fig. 5B).

\section{Functional Enrichment of Putatively AhR, COUP-TFII and HNF4 $\alpha$ Co-Regulated Genes in Mice Treated} with $30 \mu \mathrm{g} / \mathbf{k g}$ for 28 days - A total of 2,680 hepatic DEGs from mice treated with $30 \mu \mathrm{g} / \mathrm{kg}$ TCDD every 4 days for 28 days that exhibited AhR, COUP-TFII and HNF4a genomic binding $(6,376)$ were assessed for functional enrichment (Table 1; Supp. File 2). Analysis indicated that effects on diurnal regulated genes were over-represented, with 1,222 diurnal DEGs exhibiting differential expression (Table 1), followed by markers for portal hepatocytes (326 DEGs), midcentral hepatocytes (292 DEGs) and central hepatocytes (203 DEGs). 
bioRxiv preprint doi: https://doi.org/10.1101/2021.06.18.448955; this version posted June 18, 2021. The copyright holder for this preprint

(which was not certified by peer review) is the author/funder, who has granted bioRxiv a license to display the preprint in perpetuity. It is made available under aCC-BY-NC-ND 4.0 International license.

Furthermore, of the 726 genes associated with the primary human hepatocyte secretome, 211 were differentially expressed (81 repressed, 31 induced) with 103 DEGs (100 repressed, 3 induced) out of 181 being specific to the liver.

Putatively co-regulated liver-specific DEGs were examined further for AhR, COUP-TFII, and HNF4a intersections associated with the reported loss of the liver functional "phenotype" following TCDD treatment (Nault et al., 2017a). To assess the unique contributions of each transcription factor in modulating the expression of liver-specific genes, we further evaluated the 156 DEGs following treatment with $30 \mu \mathrm{g} / \mathrm{kg}$ TCDD every 4 days for 28 days (Fig. 6A). Analysis indicated AhR enrichment for $53.8 \%$ of liver-specific DEGs while COUPTFII and HNF4a binding within the intragenic region was more limited and included positive as well as negative differential enrichment when compared to a random list of DEGs in the RNAseq dataset. This suggests possible cooperation between AhR, COUP-TFII, and HNF4a in regulating differential gene expression following TCDD treatment (Fig. 6B). Of the ranked over-representation analysis, 62 DEGs possessed an increase of AhR binding, a decrease of COUP-TFII binding, and no change in HNF4a binding was the most over-represented binding pattern for liver-specific DEGs ( $p$-value = 6.78E-09; Fig. 6B). In addition, increased AhR and HNF4a binding, with and without decreased COUP-TFII (48 and 33 DEGs, respectively) were also a highly ranked binding patterns within liver-specific DEGs. ChIPseq data were mapped onto RNAseq data for the 156 liver-specific DEGs (Fig. 6C). Of the 156 liver-specific DEGs, only four (Cyp1a2, Igfbp1, Ephx1, Ugt2b35) were induced following treatment with 30 $\mathrm{g} / \mathrm{kg}$ TCDD. Integrated ChIPseq and RNAseq data suggests that dose-dependent repression of almost all liver-specific DEGs correlates with an increase in AhR and HNF4a binding, and a decrease in COUP-TFII binding. The effect of TCDD on the hepatocyte secretome gene set was also examined of loss of liver differentiation, which includes assessing genes associated with liver function. This includes assessing the genes encoding the liver secretome to evaluate hepatocyte changes in response to TCDD, as well as assess HNF4a-dependent genes since liver differentiation relies so heavily on HNF4a signaling.

Identification of AhR, COUP-TFII and HNF4a Binding Patterns in the Liver Secretome - Hepatocytes are responsible for the production and secretion of diverse proteins such as hepatokines, plasma proteins, and coagulation factors. Previous studies have identified 691 potentially secreted proteins in primary human hepatocytes (PHHs) using liquid-chromatography tandem mass spectrometry (Franko et al., 2019). Human genes encoding these 691 proteins were mapped to 726 mouse orthologues using biomaRt (Durinck et al., 2009). GSEA of mouse orthologues revealed that the PHH gene set was largely repressed (normalized enrichment score $=-2.32$ ) by $30 \mu \mathrm{g} / \mathrm{kg}$ TCDD every 4 days for 28 days (Fig. 7A). Of the $726 \mathrm{mouse} \mathrm{PHH}$ orthologues, 383 were differentially expressed by TCDD (Fig 7B). The binding pattern for PHH secretome DEGs favored an increase in AhR and HNF4a binding, and a decrease in COUP-TFIl binding following TCDD treatment (Fig 7C). Specifically, 180 DEGs only exhibited an increase in AhR binding ( $p$-value = 5.92E-11), followed by the DEGs with increased AhR binding and decreased COUP-TFII binding (113 genes; $p$-value = 5.43E-07) or increased HNF4a binding (79 genes; $p$-value $=8.45 \mathrm{E}-04$ ). Collectively, the integration of ChIPseq 
and RNAseq data suggested that TCDD-elicited PHH secretome gene repression trended toward an increase in AhR and HNF4a binding and a decrease of COUP-TFII binding events.

Identification of AhR, COUP-TFII and HNF4a Binding Patterns in HNF4a-Dependent Genes - HNF4a is a key regulator of liver development (Parviz et al., 2003) and plays a pivotal role in liver homeostasis (Bonzo et al., 2012). Hepatocyte-specific ablation of HNF4a in mice resulted in the identification of 877 DEGs confirming the importance of hepatic HNF4a-signaling (Walesky et al., 2013). To assess the effect of TCDD on hepatocyte differentiation and function, GSEA of 576 hepatocyte-specific HNF4a-dependent genes revealed an overall repression in mice treated with $30 \mu \mathrm{g} / \mathrm{kg}$ TCDD every 4 days for 28 days (normalized enrichment score = -2.64; Fig. 8A, B). Over-representation of transcription factor binding patterns for these 576 genes identified an increase in AhR binding (252 genes; $p$-value $=4.30 \mathrm{E}-11$ ), followed by increased AhR and decreased COUP-TFII binding (166 genes; $p$-value $=5.43 \mathrm{E}-07$ ), or increased AhR and increased COUP-TFII binding (75 genes; $p$-value = 8.45E-04) (Fig. 8C). 109 DEGs exhibited an increase in AhR and COUP-TFII binding ( $p$-value $=1.36 \mathrm{E}-03)$. Collectively, the repression of HNF4a-dependent genes by TCDD trended toward an increase in AhR with mixed effects on COUP-TFII binding events. 


\section{DISCUSSION}

The present study examined the effect of TCDD on AhR, HNF4a and COUP-TFII genomic binding with subsequent effects on the expression of genes associated with liver function and hepatocyte differentiation. As a potent AhR agonist, TCDD dysregulates a plethora of hepatic functions in rodents including lipoprotein assembly and export metabolism (Angrish et al., 2013; Nault et al., 2017b), bile acid homeostasis (Fader et al., 2017b; Forgacs et al., 2012), cholesterol metabolism (Angrish et al., 2013; Nault et al., 2017b), lipid metabolism (Angrish et al., 2013; Cholico et al., 2021; Nault et al., 2017b), glucose metabolism (Fader et al., 2019; Nault et al., 2016a, 2016b), iron and heme homeostasis (Fader et al., 2017a), one-carbon metabolism (Fling et al., 2020), and cobalamin-dependent reactions (Orlowska et al., 2021). Previous studies have established that the activated AhR can bind to DNA motif as a heterodimer with ARNT and associated with other transcription factors such as COUP-TF, HIF, HNF4, LRH1, NRF1, PPAR, and RXR (Dere et al., 2011).

Analysis of published AhR ChIPseq data (Nault et al., 2016b) revealed HNF4a and COUP-TFII binding sited were over-represented within sequences under regions of enriched AhR, further alluding to interactions between the three transcription factors in regulating differential gene expression in the liver. Evaluation of differentially enriched binding sites suggests AhR co-operates with COUP-TFII and HNF4a enriched regions as suggested by the $47.85 \%$ and $70.09 \%$ of overlapping peaks with AhR, respectively. Due to ChIPseq limitations, it is not possible to definitively conclude if this involved physical interactions between AhR. COUPTFIl and/or HNF4a. Previous co-immunoprecipitation studies show COUP-TFI interacts with the AhR in MCF-7 cells and reported increased COUP-TFI expression inhibited TCDD-mediated luciferase activity under the control of the CYP1A1 promoter (Klinge et al., 2000), an established AhR target gene. Furthermore, COUP-TFI binds to DREs (Klinge et al., 2000), the AhR binding motif.

Although previous results showed AhR and COUP-TFI (not COUP-TFII) cooperation, similar cooperative events are likely to occur between AhR and COUP-TFII. COUP-TFI and COUP-TFII share a high degree of protein homology with $98 \%$ similarity in the DNA binding domain and $96 \%$ in the ligand binding domain (Wang et al., 1991), suggesting they may possess overlapping protein interactions and functions (Polvani et al., 2019). For example, both COUP-TFI and COUP-TFII form heterodimers with the retinoid $X$ receptor $(\mathrm{RXR})$ to repress gene expression as well as compete for DNA binding with other transcription factors such as PPAR and HNF4 (Ashraf et al., 2019) (Kliewer et al., 1992; Kruse et al., 2008). Although COUP-TFs passively dysregulate HNF4a signaling events, direct interactions between COUP-TFII and HNF4a have been reported. COUP-TFII can either inhibit or promote HNF4a transactivation depending on the promoter, cell and tissue context (Schaeffer et al., 1993) (Stroup and Chiang, 2000). In the liver, COUP-TFII has been implicated in the regulation of lipid and glucose metabolism (Ashraf et al., 2019), while both HNF4a and COUP-TFII bind to the PPARa promoter region to impose opposite regulatory effects on $\beta$-oxidation (Pineda Torra et al., 2002). Specifically, HNF4a induces PPARa transcription, while COUP-TFIl competes with HNF4a for PPAR regulatory region binding thereby causing PPARa repression (Pineda Torra et al., 2002). Consequently, dysregulation of HNF4a- and COUP-TFIl-signaling is likely involved, albeit it through still to be determined 
bioRxiv preprint doi: https://doi.org/10.1101/2021.06.18.448955; this version posted June 18, 2021. The copyright holder for this preprint (which was not certified by peer review) is the author/funder, who has granted bioRxiv a license to display the preprint in perpetuity. It is made available under aCC-BY-NC-ND 4.0 International license.

mechanisms, in the progression of steatosis to hepatotoxicity and steatohepatitis with fibrosis by TCDD (Angrish et al., 2013; Nault et al., 2016c; Pierre et al., 2014).

HNF4a also serves a broader role beyond the regulation of hepatic metabolic events. The most prominent involve liver morphogenesis (Duncan et al., 1994; Parviz et al., 2003), and hepatocyte differentiation (Hayhurst et al., 2001; Morimoto et al., 2017). Previous studies suggest TCDD induces the loss of the liverspecific phenotype as evidenced by dysregulation of liver-specific gene expression (Nault et al., 2017a). In the present study, assessment of liver-specific DEGS following treatment with $30 \mu \mathrm{g} / \mathrm{kg}$ TCDD identified an association between reduced COUP-TFII binding and increased HNF4a binding in the presence of AhR genomic enrichment. Since HNF4a-signaling is required to maintain hepatic cell differentiation (Hayhurst et al., 2001), we evaluated the expression of genes previously identified to be dependent on this signaling pathway. These HNF4a-dependent genes in the liver were previously identified using a hepatocyte-specific HNF4a knockout model (Walesky et al., 2013). TCDD induced a cell de-differentiation phenotype, as evidenced by the overall repression of HNF4a-dependent gene expression involving a decrease in COUP-TFII binding with increased HNF4a binding. Loss of the hepatocyte phenotype was also evident in the overall repression of genes encoding the hepatic secretome. Similarly, repression of the hepatic secretome following TCDD treatment coincided with reduced COUP-TFII binding and increased HNF4a binding in the presence of AhR genomic enrichment. It is important to note, the hepatic secretome (Franko et al., 2019) only represents a set of secreted proteins from hepatocytes and does not account for secreted proteins produced by other hepatic cell types such as endothelial cells, hepatic stellate cells, cholangiocytes, and resident macrophages. Although loss of hepatocyte differentiation appears to occur, at least in part, indirectly through changes in HNF4a signaling, other mechanisms are also likely to contribute.

Hepatic cell de-differentiation following TCDD treatment plausibly occurs in part through changes in AhR signaling. Despite few studies linking AhR signaling to hepatic cell differentiation, AhR has been shown to regulate cell differentiation events in other tissues. For example, in vitro TCDD perturbed cardiomyocyte differentiation (Wang et al., 2013). Additionally, dysregulation of AhR-signaling has also been shown to promote proliferation and differentiation of human hematopoietic stem cells (HSCs) (Boitano et al., 2010). Under homeostatic conditions, HSCs remain in a quiescent state. However, following tissue damage or pathogen exposure HSCs are activated and subsequently proliferative. Continuously treated primary human $\mathrm{CD}^{+} 4^{+}$(a surface marker of HSCs) cells with StemRegenin 1, an AhR antagonist, for 53 weeks increased CD34 ${ }^{+}$cells by 73-fold (Boitano et al., 2010), further implicating AhR signaling in HSC differentiation. AhR deficient mice also exhibit elevated HSC proliferation with increased lymphocyte production and reduced levels of erythrocytes, neutrophils and monocytes (Singh et al., 2011). Interestingly, DREs are over-represented within 1,000 bps of HSC-enriched gene TSSs suggesting AhR regulation (Gazit et al., 2013). Moreover, AhR signaling plays a role stem cell differentiation into intestinal epithelial cells (Metidji et al., 2018). Although WNT $\beta$-Catenin mediates intestinal stem cell proliferation and differentiation (Sato and Clevers, 2013), mice with dysregulated intestinal AhR signaling do not exhibit cell proliferation and intestinal crypt stem cell differentiation (Metidji et al., 2018). In the mouse liver, crosstalk between AhR and Wnt/ $\beta$-catenin signaling has 
been reported (Schneider et al., 2014). TCDD also downregulates key Wnt/ $\beta$-catenin pathway target genes in liver progenitor cells further implicating AhR signaling in hepatocyte differentiation. Collectively, these data suggest the AhR serves an important role in tissue-specific cell differentiation and is likely involved in hepatocyte differentiation.

In summary, metabolic reprogramming events caused by TCDD include dysregulation of the hepatic secretome as well as hepatocyte differentiation. These changes appear to involve intersections between AhR, HNF4 $\alpha$ and COUP-TFII. Further studies are required to assess the co-operation between AhR, HNF4a and COUP-TFII, and to further define the types of interactions. Since the enrichment of AhR binding includes DNA motifs for a wide array of transcriptional regulators, it is also possible that TCDD-mediated hepatotoxicity occurs through mechanisms involving other transcription factors. The relevance of these interactions in human models also warrants further investigation. 
bioRxiv preprint doi: https://doi.org/10.1101/2021.06.18.448955; this version posted June 18, 2021. The copyright holder for this preprint (which was not certified by peer review) is the author/funder, who has granted bioRxiv a license to display the preprint in perpetuity. It is made available under aCC-BY-NC-ND 4.0 International license.

\section{REFERENCES}

Angrish, M.M., Dominici, C.Y., Zacharewski, T.R., 2013. TCDD-Elicited effects on liver, serum, and adipose lipid composition in C57BL/6 mice. Toxicol. Sci. 131, 108-115. https://doi.org/10.1093/toxsci/kfs277

Angrish, M.M., Mets, B.D., Jones, A.D., Zacharewski, T.R., 2012. Dietary fat is a lipid source in 2,3,7,8Tetrachlorodibenzo-p-Dioxin (TCDD)-elicited hepatic steatosis in C57BL/6 mice. Toxicol. Sci. 128, 377386. https://doi.org/10.1093/toxsci/kfs155

Ashraf, U.M., Sanchez, E.R., Kumarasamy, S., 2019. COUP-TFII revisited: Its role in metabolic gene regulation. Steroids 141, 63-69. https://doi.org/10.1016/j.steroids.2018.11.013

Boitano, A.E., Wang, J., Romeo, R., Bouchez, L.C., Parker, A.E., Sutton, S.E., Walker, J.R., Flaveny, C.A., Perdew, G.H., Denison, M.S., Schultz, P.G., Cooke, M.P., 2010. Aryl Hydrocarbon Receptor Antagonists Promote the Expansion of Human Hematopoietic Stem Cells. Science (80-. ). 329, 1345-1348.

https://doi.org/10.1126/science.1191536

Bonzo, J.A., Ferry, C.H., Matsubara, T., Kim, J.H., Gonzalez, F.J., 2012. Suppression of hepatocyte proliferation by hepatocyte nuclear factor $4 a$ in adult mice. J. Biol. Chem. 287, 7345-7356. https://doi.org/10.1074/jbc.M111.334599

Boverhof, D.R., Burgoon, L.D., Tashiro, C., Chittim, B., Harkema, J.R., Jump, D.B., Zacharewski, T.R., 2005. Temporal and dose-dependent hepatic gene expression patterns in mice provide new insights into TCDDmediated hepatotoxicity. Toxicol. Sci. 85, 1048-1063. https://doi.org/10.1093/toxsci/kfi162

Cholico, G.N., Fling, R.R., Zacharewski, N.A., Fader, K.A., Nault, R., Zacharewski, T., 2021. Thioesterase induction by 2,3,7,8-tetrachlorodibenzo-p-dioxin results in a futile cycle that inhibits hepatic $\beta$-oxidation. bioRxiv 2021.01.21.427582. https://doi.org/10.1101/2021.01.21.427582

de Matos Simoes, R., Emmert-Streib, F., 2012. Bagging statistical network inference from large-scale gene expression data. PLoS One 7. https://doi.org/10.1371/journal.pone.0033624

Denison, M.S., Soshilov, A.A., He, G., Degroot, D.E., Zhao, B., 2011. Exactly the same but different:

Promiscuity and diversity in the molecular mechanisms of action of the aryl hydrocarbon (dioxin) receptor. Toxicol. Sci. 124, 1-22. https://doi.org/10.1093/toxsci/kfr218

Dere, E., Lo, R., Celius, T., Matthews, J., Zacharewski, T.R., 2011. Integration of Genome-Wide Computation DRE Search, AhR ChIP-chip and Gene Expression Analyses of TCDD-Elicited Responses in the Mouse Liver. BMC Genomics 12, 365. https://doi.org/10.1186/1471-2164-12-365

Doskey, C.M., Fader, K.A., Nault, R., Lydic, T., Matthews, J., Potter, D., Sharratt, B., Williams, K., Zacharewski, T., 2020. 2,3,7,8-Tetrachlorodibenzo-p-dioxin (TCDD) alters hepatic polyunsaturated fatty acid metabolism and eicosanoid biosynthesis in female Sprague-Dawley rats. Toxicol. Appl. Pharmacol. 398, 115034. https://doi.org/10.1016/j.taap.2020.115034

Duncan, S.A., Manova, K., Chen, W.S., Hoodless, P., Weinstein, D.C., Bachvarova, R.F., Darnell, J.E., 1994. Expression of transcription factor HNF-4 in the extraembryonic endoderm, gut, and nephrogenic tissue of the developing mouse embryo: HNF-4 is a marker for primary endoderm in the implanting blastocyst.

Proc. Natl. Acad. Sci. U. S. A. 91, 7598-7602. https://doi.org/10.1073/pnas.91.16.7598

Durinck, S., Spellman, P.T., Birney, E., Huber, W., 2009. Mapping identifiers for the integration of genomic 
bioRxiv preprint doi: https://doi.org/10.1101/2021.06.18.448955; this version posted June 18, 2021. The copyright holder for this preprint (which was not certified by peer review) is the author/funder, who has granted bioRxiv a license to display the preprint in perpetuity. It is made available under aCC-BY-NC-ND 4.0 International license.

datasets with the R/ Bioconductor package biomaRt. Nat. Protoc. 4, 1184-1191.

https://doi.org/10.1038/nprot.2009.97

Fader, K.A., Nault, R., Ammendolia, D.A., Harkema, J.R., Williams, K.J., Crawford, R.B., Kaminski, N.E., Potter, D., Sharratt, B., Zacharewski, T.R., 2015. 2,3,7,8-tetrachlorodibenzo-p-dioxin alters lipid metabolism and depletes immune cell populations in the Jejunum of C57BL/6 mice. Toxicol. Sci. 148, 567-580. https://doi.org/10.1093/toxsci/kfv206

Fader, K.A., Nault, R., Doskey, C.M., Fling, R.R., Zacharewski, T.R., 2019. 2,3,7,8-Tetrachlorodibenzo-p-dioxin abolishes circadian regulation of hepatic metabolic activity in mice. Sci. Rep. 9, 1-18. https://doi.org/10.1038/s41598-019-42760-3

Fader, K.A., Nault, R., Kirby, M.P., Markous, G., Matthews, J., Zacharewski, T.R., 2017a. Convergence of hepcidin deficiency, systemic iron overloading, heme accumulation, and REV-ERBa/ $\beta$ activation in aryl hydrocarbon receptor-elicited hepatotoxicity. Toxicol. Appl. Pharmacol. 321, 1-17. https://doi.org/10.1016/j.taap.2017.02.006

Fader, K.A., Nault, R., Zhang, C., Kumagai, K., Harkema, J.R., Zacharewski, T.R., 2017b. 2,3,7,8-

Tetrachlorodibenzo-p-dioxin (TCDD)-elicited effects on bile acid homeostasis: Alterations in biosynthesis, enterohepatic circulation, and microbial metabolism. Sci. Rep. 7, 5921. https://doi.org/10.1038/s41598017-05656-8

Fernandez-Salguero, P.M., Hilbert, D.M., Rudikoff, S., Ward, J.M., Gonzalez, F.J., 1996. Aryl-hydrocarbon receptor-deficient mice are resistant to 2,3,7,8-tetrachlorodibenzo-p-dioxin-induced toxicity. Toxicol. Appl. Pharmacol. 140, 173-9. https://doi.org/10.1006/taap.1996.0210

Fling, R.R., Doskey, C.M., Fader, K.A., Nault, R., Zacharewski, T.R., 2020. 2,3,7,8-Tetrachlorodibenzo-p-dioxin (TCDD) dysregulates hepatic one carbon metabolism during the progression of steatosis to steatohepatitis with fibrosis in mice. Sci. Rep. 10, 1-15. https://doi.org/10.1038/s41598-020-71795-0 Forgacs, A.L., Kent, M.N., Makley, M.K., Mets, B., DelRaso, N., Jahns, G.L., Burgoon, L.D., Zacharewski, T.R., Reo, N. V., 2012. Comparative metabolomic and genomic analyses of TCDD-elicited metabolic disruption in mouse and rat liver. Toxicol. Sci. 125, 41-55. https://doi.org/10.1093/toxsci/kfr262

Franko, A., Hartwig, S., Kotzka, J., Ruoß, M., Nüssler, A.K., Königsrainer, A., Häring, H.U., Lehr, S., Peter, A., 2019. Identification of the secreted proteins originated from primary human hepatocytes and HepG2 cells. Nutrients 11, 1-12. https://doi.org/10.3390/nu11081795

Gazit, R., Garrison, B.S., Rao, T.N., Shay, T., Costello, J., Ericson, J., Kim, F., Collins, J.J., Regev, A., Wagers, A.J., Rossi, D.J., 2013. Transcriptome analysis identifies regulators of hematopoietic stem and progenitor cells. Stem Cell Reports 1, 266-280. https://doi.org/10.1016/j.stemcr.2013.07.004 Hayhurst, G.P., Lee, Y.-H., Lambert, G., Ward, J.M., Gonzalez, F.J., 2001. Hepatocyte Nuclear Factor 4a (Nuclear Receptor 2A1) Is Essential for Maintenance of Hepatic Gene Expression and Lipid Homeostasis. Mol. Cell. Biol. 21, 1393-1403. https://doi.org/10.1128/mcb.21.4.1393-1403.2001

Kliewer, S.A., Umesono, K., Heyman, R.A., Mangelsdorf, D.J., Dyck, J.A., Evans, R.M., 1992. Retinoid X receptor-COUP-TF interactions modulate retinoic acid signaling. Proc. Natl. Acad. Sci. U. S. A. 89, 14481452. https://doi.org/10.1073/pnas.89.4.1448 
Klinge, C.M., Kaur, K., Swanson, H.I., 2000. The aryl hydrocarbon receptor interacts with estrogen receptor alpha and orphan receptors COUP-TFI and ERRa1. Arch. Biochem. Biophys. 373, 163-174. https://doi.org/10.1006/abbi.1999.1552

Kruse, S.W., Suino-Powell, K., Zhou, X.E., Kretschman, J.E., Reynolds, R., Vonrhein, C., Xu, Y., Wang, L., Tsai, S.Y., Tsai, M.-J., Xu, H.E., 2008. Identification of COUP-TFII Orphan Nuclear Receptor as a Retinoic Acid-Activated Receptor. PLoS Biol. 6, e227. https://doi.org/10.1371/journal.pbio.0060227

Larigot, L., Juricek, L., Dairou, J., Coumoul, X., 2018. AhR signaling pathways and regulatory functions. Biochim. Open 7, 1-9. https://doi.org/10.1016/j.biopen.2018.05.001

Lu, H., Cui, W., Klaassen, C.D., 2011. Nrf2 protects against 2,3,7,8-tetrachlorodibenzo-p-dioxin (TCDD)induced oxidative injury and steatohepatitis. Toxicol. Appl. Pharmacol. 256, 122-135.

https://doi.org/10.1016/j.taap.2011.07.019

Metidji, A., Omenetti, S., Crotta, S., Li, Y., Nye, E., Ross, E., Li, V., Maradana, M.R., Schiering, C., Stockinger, B., 2018. The Environmental Sensor AHR Protects from Inflammatory Damage by Maintaining Intestinal Stem Cell Homeostasis and Barrier Integrity. Immunity 49, 353-362.e5.

https://doi.org/10.1016/j.immuni.2018.07.010

Morimoto, A., Kannari, M., Tsuchida, Y., Sasaki, S., Saito, C., Matsuta, T., Maeda, T., Akiyama, M., Nakamura, T., Sakaguchi, M., Nameki, N., Gonzalez, F.J., Inoue, Y., 2017. An HNF4a-microRNA-194/192 signaling axis maintains hepatic cell function. J. Biol. Chem. 292, 10574-10585.

https://doi.org/10.1074/jbc.M117.785592

Murphy, K.A., Villano, C.M., Dorn, R., White, L.A., 2004. Interaction between the aryl hydrocarbon receptor and retinoic acid pathways increases matrix metalloproteinase-1 expression in keratinocytes. J. Biol. Chem. 279, 25284-25293. https://doi.org/10.1074/jbc.M402168200

Nault, R., Doskey, C.M., Fader, K.A., Rockwell, C.E., Zacharewski, T., 2018. Comparison of hepatic NRF2 and aryl hydrocarbon receptor binding in 2,3,7,8-tetrachlorodibenzo-p-dioxin-treated mice demonstrates NRF2-independent PKM2 induction. Mol. Pharmacol. 94, 876-884.

https://doi.org/10.1124/mol.118.112144

Nault, R., Fader, K.A., Ammendolia, D.A., Dornbos, P., Potter, D., Sharratt, B., Kumagai, K., Harkema, J.R., Lunt, S.Y., Matthews, J., Zacharewski, T., 2016a. Dose-dependent metabolic reprogramming and differential gene expression in TCDD-elicited hepatic fibrosis. Toxicol. Sci. 154, 253-266. https://doi.org/10.1093/toxsci/kfw163

Nault, R., Fader, K.A., Harkema, J.R., Zacharewski, T., 2017a. Loss of liver-specific and sexually dimorphic gene expression by aryl hydrocarbon receptor activation in C57BL/6 mice. PLoS One 12, 1-17. https://doi.org/10.1371/journal.pone.0184842

Nault, R., Fader, K.A., Kirby, M.P., Ahmed, S., Matthews, J., Jones, A.D., Lunt, S.Y., Zacharewski, T.R., 2016b. Pyruvate kinase isoform switching and hepatic metabolic reprogramming by the environmental contaminant 2,3,7,8-tetrachlorodibenzo-p-dioxin. Toxicol. Sci. 149, 358-371. https://doi.org/10.1093/toxsci/kfv245

Nault, R., Fader, K.A., Kopec, A.K., Harkema, J.R., Zacharewski, T.R., Luyendyk, J.P., 2016c. Coagulation- 
bioRxiv preprint doi: https://doi.org/10.1101/2021.06.18.448955; this version posted June 18, 2021. The copyright holder for this preprint (which was not certified by peer review) is the author/funder, who has granted bioRxiv a license to display the preprint in perpetuity. It is made available under aCC-BY-NC-ND 4.0 International license.

driven hepatic fibrosis requires protease activated receptor-1 (PAR-1) in a mouse model of TCDD-elicited steatohepatitis. Toxicol. Sci. 154, 381-391. https://doi.org/10.1093/TOXSCI/KFW175

Nault, R., Fader, K.A., Lydic, T.A., Zacharewski, T.R., 2017b. Lipidomic Evaluation of Aryl Hydrocarbon Receptor-Mediated Hepatic Steatosis in Male and Female Mice Elicited by 2,3,7,8-Tetrachlorodibenzo-pdioxin. Chem. Res. Toxicol. 30, 1060-1075. https://doi.org/10.1021/acs.chemrestox.6b00430 Ohtake, F., Takeyama, K. ichi, Matsumoto, T., Kitagawa, H., Yamamoto, Y., Nohara, K., Tohyama, C., Krust, A., Mimura, J., Chambon, P., Yanagisawa, J., Fujii-Kuriyama, Y., Kato, S., 2003. Modulation of oestrogen receptor signalling by association with the activated dioxin receptor. Nature 423, 545-550. https://doi.org/10.1038/nature01606

Orlowska, K., Fling, R.R., Nault, R., Zacharewski, T., 2021. 2,3,7,8-Tetrachlorodibenzo-p-dioxin elicited decreases in cobalamin inhibits methylmalonyl-CoA mutase activity redirecting propionyl-CoA metabolism to the $\beta$-oxidation-like pathway resulting in hepatic accumulation of the toxic intermediate acrylyl-CoA. bioRxiv 2021.03.24.436837. https://doi.org/https://doi.org/10.1101/2021.03.24.436837

Parviz, F., Matullo, C., Garrison, W.D., Savatski, L., Adamson, J.W., Ning, G., Kaestner, K.H., Rossi, J.M., Zaret, K.S., Duncan, S.A., 2003. Hepatocyte nuclear factor $4 a$ controls the development of a hepatic epithelium and liver morphogenesis. Nat. Genet. 34, 292-296. https://doi.org/10.1038/ng1175

Pierre, S., Chevallier, A., Teixeira-Clerc, F., Ambolet-Camoit, A., Bui, L.C., Bats, A.S., Fournet, J.C., Fernandez-Salguero, P.M., Aggerbeck, M., Lotersztajn, S., Barouki, R., Coumoul, X., 2014. Aryl hydrocarbon receptor-dependent induction of liver fibrosis by dioxin. Toxicol. Sci. 137, 114-124. https://doi.org/10.1093/toxsci/kft236

Pineda Torra, I., Jamshidi, Y., Flavell, D.M., Fruchart, J.-C., Staels, B., 2002. Characterization of the Human PPARa Promoter: Identification of a Functional Nuclear Receptor Response Element. Mol. Endocrinol. 16, 1013-1028. https://doi.org/10.1210/mend.16.5.0833

Polvani, S., Pepe, S., Milani, S., Galli, A., 2019. COUP-TFII in Health and Disease. Cells 9, 101. https://doi.org/10.3390/cells9010101

Rothhammer, V., Quintana, F.J., 2019. The aryl hydrocarbon receptor: an environmental sensor integrating immune responses in health and disease. Nat. Rev. Immunol. 19, 184-197. https://doi.org/10.1038/s41577-019-0125-8

Sato, T., Clevers, H., 2013. Growing self-organizing mini-guts from a single intestinal stem cell: Mechanism and applications. Science (80-. ). 340, 1190-1194. https://doi.org/10.1126/science.1234852

Schaeffer, E., Guillou, F., Part, D., Zakin, M.M., 1993. A different combination of transcription factors modulates the expression of the human transferrin promoter in liver and Sertoli cells. J. Biol. Chem. 268, 23399-23408. https://doi.org/10.1016/S0021-9258(19)49476-3

Schneider, A.J., Branam, A.M., Peterson, R.E., 2014. Intersection of AHR and Wnt signaling in development, health, and disease. Int. J. Mol. Sci. 15, 17852-17885. https://doi.org/10.3390/ijms151017852

Singh, K.P., Garrett, R.W., Casado, F.L., Gasiewicz, T.A., 2011. Aryl hydrocarbon receptor-null allele mice have hematopoietic stem/progenitor cells with abnormal characteristics and functions. Stem Cells Dev. 20, 769-784. https://doi.org/10.1089/scd.2010.0333 
Stroup, D., Chiang, J.Y.L., 2000. HNF4 and COUP-TFII interact to modulate transcription of the cholesterol 7ahydroxylase gene (CYP7A1). J. Lipid Res. 41, 1-11. https://doi.org/10.1016/s0022-2275(20)32068-x

Subramanian, A., Tamayo, P., Mootha, V.K., Mukherjee, S., Ebert, B.L., Gillette, M.A., Paulovich, A., Pomeroy, S.L., Golub, T.R., Lander, E.S., Mesirov, J.P., 2005. Gene set enrichment analysis: A knowledge-based approach for interpreting genome-wide expression profiles. Proc. Natl. Acad. Sci. U. S. A. 102, 1554515550. https://doi.org/10.1073/pnas.0506580102

Walesky, C., Edwards, G., Borude, P., Gunewardena, S., O’Neil, M., Yoo, B., Apte, U., 2013. Hepatocyte nuclear factor 4 alpha deletion promotes diethylnitrosamine-induced hepatocellular carcinoma in rodents. Hepatology 57, 2480-2490. https://doi.org/10.1002/hep.26251

Wang, L.H., Ing, N.H., Tsai, S.Y., O’Malley, B.W., Tsai, M.J., 1991. The COUP-TFs compose a family of functionally related transcription factors. Gene Expr. 1, 207-216.

Wang, Q., Chen, J., Ko, C.I., Fan, Y., Carreira, V., Chen, Y., Xia, Y., Medvedovic, M., Puga, A., 2013. Disruption of aryl hydrocarbon receptor homeostatic levels during embryonic stem cell differentiation alters expression of homeobox transcription factors that control cardiomyogenesis. Environ. Health Perspect. 121, 1334-1343. https://doi.org/10.1289/ehp.1307297

Wilson, S.R., Joshi, A.D., Elferink, C.J., 2013. The Tumor Suppressor Kruppel-Like Factor 6 Is a Novel Aryl Hydrocarbon Receptor DNA Binding Partner. J. Pharmacol. Exp. Ther. 345, 419-429. https://doi.org/10.1124/jpet.113.203786

Yeager, R.L., Reisman, S.A., Aleksunes, L.M., Klaassen, C.D., 2009. Introducing the "TCDD-inducible AhRNrf2 gene battery." Toxicol. Sci. 111, 238-246. https://doi.org/10.1093/toxsci/kfp115 
bioRxiv preprint doi: https://doi.org/10.1101/2021.06.18.448955; this version posted June 18, 2021. The copyright holder for this preprint (which was not certified by peer review) is the author/funder, who has granted bioRxiv a license to display the preprint in perpetuity. It is made
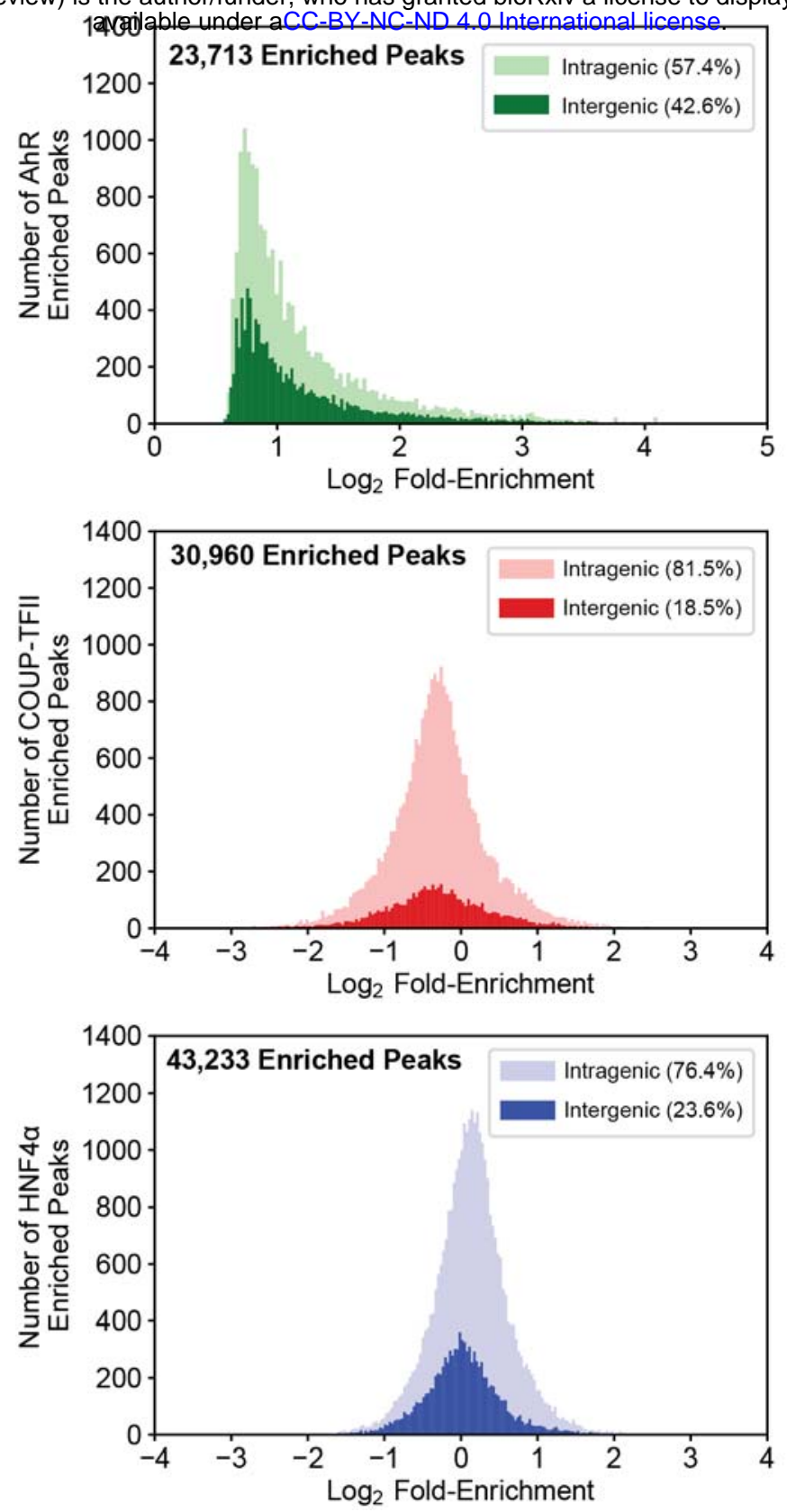

Figure 1: AhR, COUP-TFII, and HNF4a ChIPseq analysis in TCDD-treated liver samples. Mice were treated for $2 \mathrm{hrs}$ with a single oral dose of $30 \mu \mathrm{g} / \mathrm{kg}$ TCDD (or sesame oil vehicle). Liver samples were assessed for AhR, COUP-TFII, and HNF4a genomic binding enrichment using ChIPseq. $\log _{2}$ fold-enrichments were assessed for frequency of binding within intragenic (light color) and intergenic (dark color) regions. Intragenic regions are defined as $10 \mathrm{~Kb}$ upstream of the transcriptional start site (TSS) to the end of the transcribed region of a gene. Intergenic is defined as regions outside of intragenic regions. The AhR histogram is depicted as a minimum $\log _{2}$ fold-enrichment of 0 as it does not constitutively bind DNA in the absence of a ligand. 
bioRxiv preprint doi: https://doi.org/10.1101/2021.06.18.448955; this version posted June 18, 2021. The copyright holder for this preprint (which was not certified by peer review) is the author/funder, who has granted bioRxiv a license to display the preprint in perpetuity. It is made

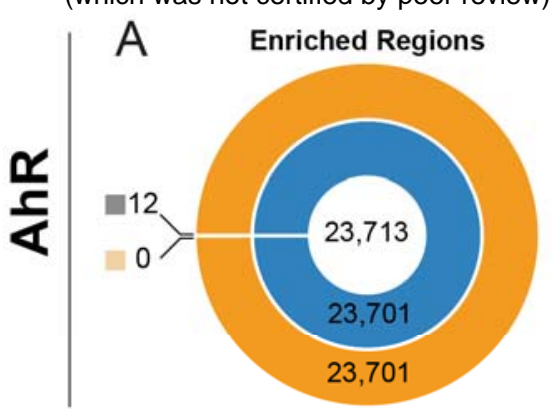
Bvailable under aCC-BY-NC-ND 4 .O International license.

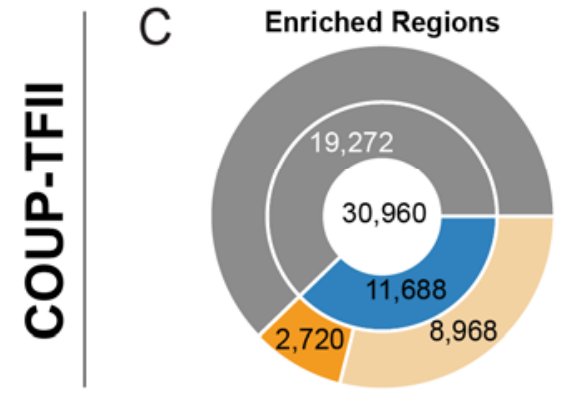

\begin{tabular}{|c|c|c|}
\hline Motif & Motif Name & $\begin{array}{l}\% \text { of Targets } \\
\text { Sequences } \\
\text { with Motif }\end{array}$ \\
\hline IE $\triangle \mathrm{CAC} C A \mathrm{~A}$ & Arnt:Ahr & $31.53 \%$ \\
\hline ATTGGSAAC & CEBP & $16.35 \%$ \\
\hline CAACAG ICAAAGTCCA & HNF4a & $13.06 \%$ \\
\hline ETTATGIAAC & HLF & $15.50 \%$ \\
\hline 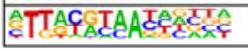 & NFIL3 & $13.14 \%$ \\
\hline
\end{tabular}
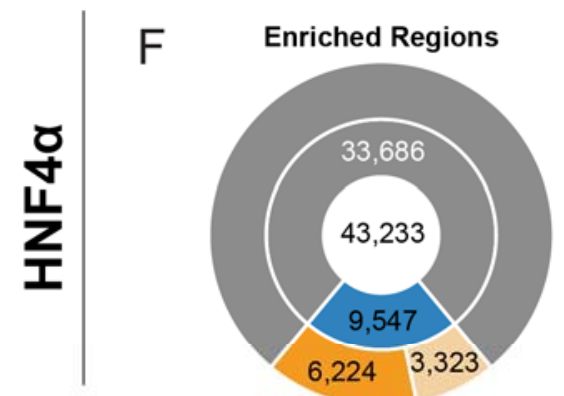

\begin{tabular}{|c|c|c|}
\hline Motif & Motif Name & \begin{tabular}{|c} 
\% of Targets \\
Sequences \\
with Motif
\end{tabular} \\
\hline SGC동두숨AGGTCA & COUP-TFII & $26.89 \%$ \\
\hline AGAGGTCA & COUP-TFII & $30.60 \%$ \\
\hline 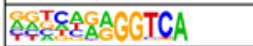 & EAR2 & $24.40 \%$ \\
\hline CACAGTCAAAGTCA & HNF4a & $11.15 \%$ \\
\hline EXAGGTCAAAGTCA & PPARa & $19.36 \%$ \\
\hline
\end{tabular}

\begin{tabular}{|c|c|c|}
\hline \multicolumn{3}{|c|}{ Negatively Differentially Enriched Motifs } \\
\hline Motif & Motif Name & $\begin{array}{c}\% \text { of Targets } \\
\text { Sequences } \\
\text { with Motif }\end{array}$ \\
\hline GGC동수셤AGGTCA & COUP-TFII & $29.03 \%$ \\
\hline AGAGGTCA & COUP-TFII & $32.62 \%$ \\
\hline 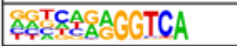 & EAR2 & $26.92 \%$ \\
\hline GAGGTCAAAGGTCA & TR4 & $5.37 \%$ \\
\hline CXAGGTCAAGGTCA & PPARa & $20.37 \%$ \\
\hline
\end{tabular}

Constitutively Bound

Differentially Enriched

Positively Differentially Enriched

Negatively Differentially Enriched

Figure 2: Over-represented motif analysis within differentially enriched peak sequences. (A, C, F) The effect of TCDD on the total number of enriched regions (center of donut plots) for AhR, COUP-TFII and HNF4a $(0.6 \geq$ fold-change $\geq 1.5$; blue regions). Differentially enriched regions were further assessed for increased (positive - increased binding) and decreased (negative - decreased binding) enrichment (shades of orange). Sequences within positive $(\mathbf{B}, \mathbf{D}, \mathbf{G})$ and negative $(\mathbf{E}, \mathbf{H})$ differentially enriched regions for each transcription factor were analyzed for enriched DNA motifs. The top 5 ranked binding motifs for each group are depicted. All over-represented motifs identified are listed in supplementary file 1. 
bioRxiv preprint doi: https://doi.org/10.1101/2021.06.18.448955; this version posted June 18, 2021. The copyright holder for this preprint (which was not certified by peer review) is the author/funder, who has granted bioRxiv a license to display the preprint in perpetuity. It is made available under aCC-BY-NC-ND 4.0 International license.

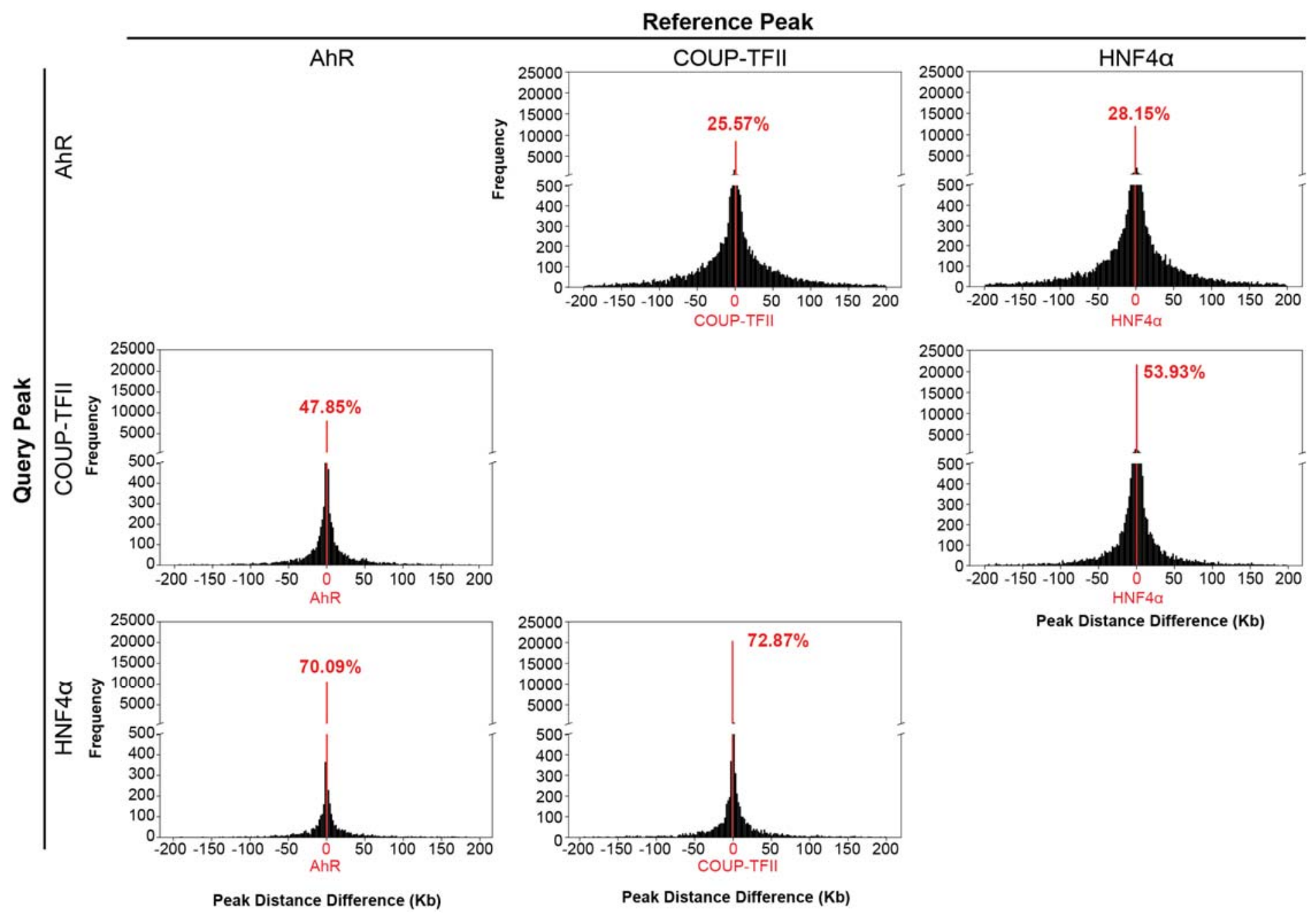

Figure 3: Evaluating overlap of differentially enriched peaks. Differentially enriched peaks for AhR, COUPTFII and HNF4a were assessed for overlap following a $2 \mathrm{hr}$ single oral gavage of $30 \mu \mathrm{g} / \mathrm{kg}$ TCDD. The distance $(\mathrm{Kb})$ prevalence between transcription factor peak centers is denoted in each histogram. The number of overlapping peaks out of the total number of peaks for the reference transcription factor is denoted in red as a percentage. 


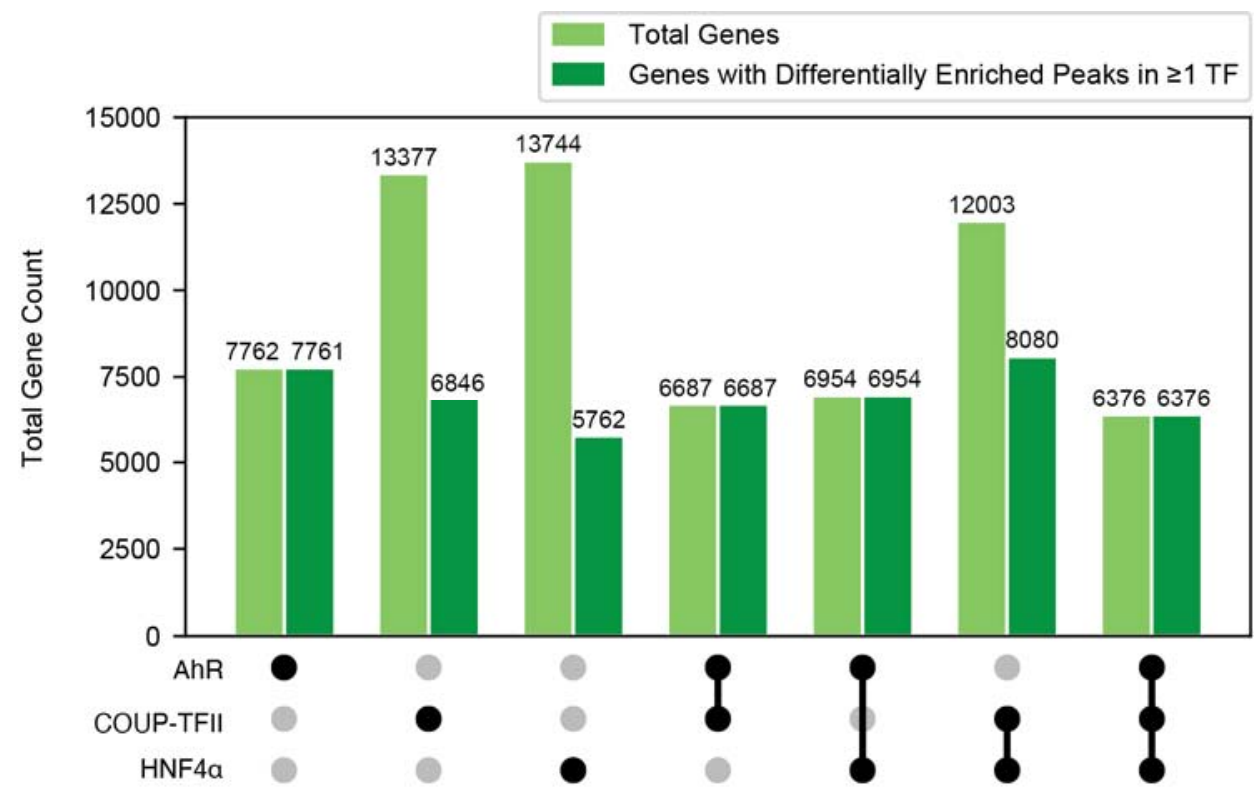

Figure 4: Evaluating putative co-regulated gene targets. The total number of hepatic genes associated with AhR, COUP-TFII and HNF4a enrichment in intragenic regions in ChIPseq data using mouse liver samples 2 hrs after TCDD treatment. Black circles denote the presence of genes for each transcription factor dataset. Common genes among transcription factor datasets are also identified and are referred to as "intersections". The number of genes possessing at least one enriched peak following TCDD treatment are denoted in dark green. 
bioRxiv preprint doi: https://doi.org/10.1101/2021.06.18.448955; this version posted June 18, 2021. The copyright holder for this preprint (which was not certified by peer review) is the author/funder, who has granted bioRxiv a license to display the preprint in perpetuity. It is made

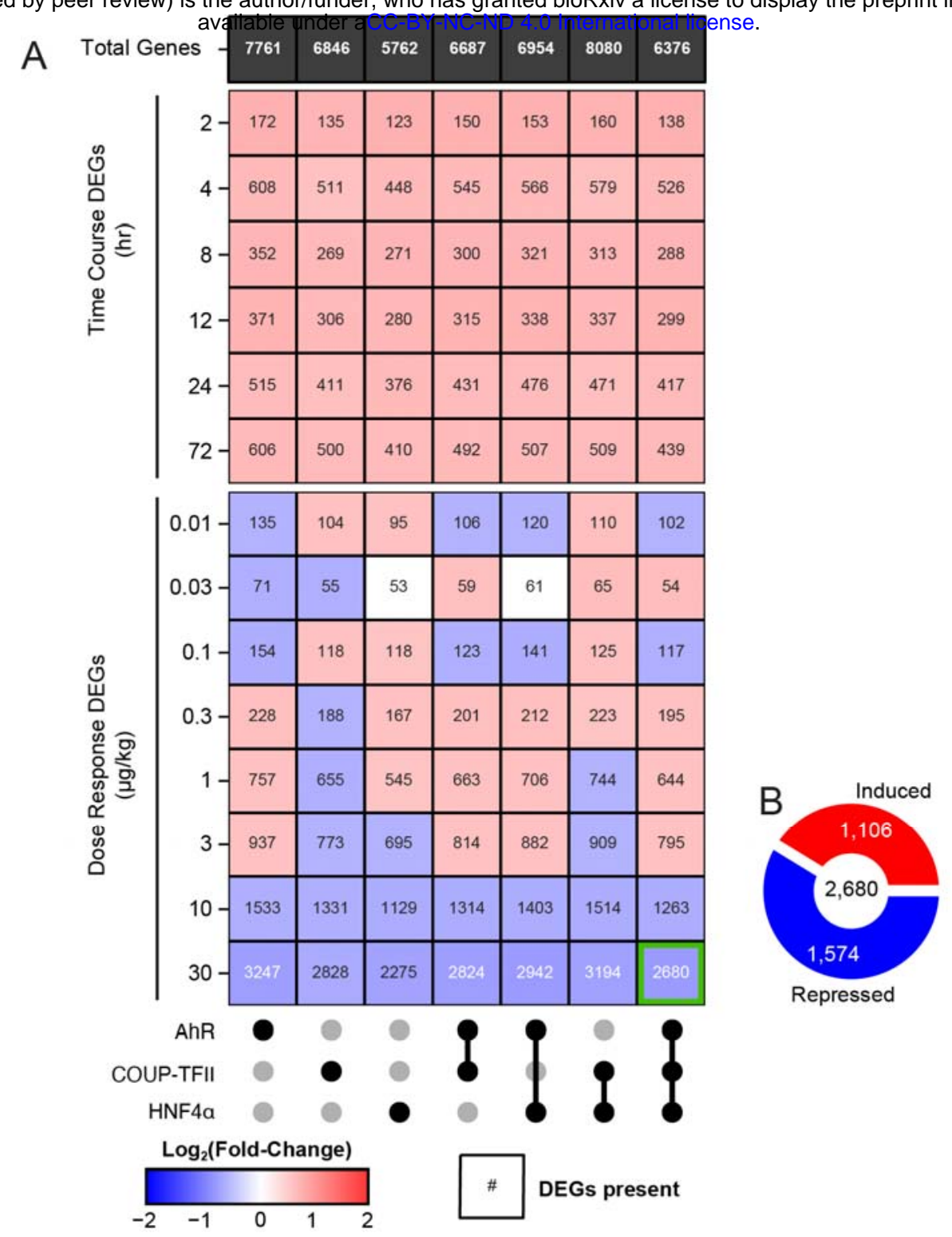

Figure 5: Gene expression of putative co-regulated genes. (A) The total number of genes with at least one enriched peak (black row) was determined for each transcription factor and their intersection (black dots). Differential gene expression (heatmap) was assessed for the transcription factor bound genes in a time course (GSE109863) and dose response (GSE87519) RNAseq dataset. The number within each tile provides the total number of differentially expressed genes (DEGs) for each individual transcription factor and their intersections. The color of the heatmap tile denotes the median $\log _{2}$ fold-change of differentially expressed genes. (B) DEGs putatively co-regulated by AhR, COUP-TFII, and HNF4a in mice gavaged with $30 \mu \mathrm{g} / \mathrm{kg}$ every 4 days for 28 days were further evaluated (genes represented in green square). The number of induced and repressed DEGs are shown in red and blue, respectively. 
bioRxiv preprint doi: https://doi.org/10.1101/2021.06.18.448955; this version posted June 18, 2021. The copyright holder for this preprint (which was not certified by peer review) is the author/funder, who has granted bioRxiv a license to display the preprint in perpetuity. It is made

Table 1: Top 20 enriched terms of treated with $30 \mu \mathrm{g} / \mathrm{kg}$ TCDD every 4 days for 28 days

\begin{tabular}{lccc}
\hline TermID & DEGs & $\begin{array}{c}\text { All Genes } \\
\text { in Term }\end{array}$ & $\begin{array}{c}\text { Adj. } \\
\text { p-Value }\end{array}$ \\
\hline TZ_DIURNAL_GENES & 1222 & 5613 & 0 \\
TZ_SCS_PORTALHEP & 326 & 581 & $6.91 \mathrm{E}-269$ \\
TZ_SCS_MIDCENTRALHEP & 292 & 563 & $1.76 \mathrm{E}-226$ \\
TZ_SCS_CENTRALHEP & 203 & 466 & $3.59 \mathrm{E}-136$ \\
GO_CC_MM_MITCCHONDRION_Ensembl & 308 & 1328 & $6.80 \mathrm{E}-120$ \\
KEGG_MM_METABOLIC_PATHWAYS_EnsembI & 290 & 1180 & $1.59 \mathrm{E}-119$ \\
HEPG2_SECRETOME & 216 & 757 & $1.53 \mathrm{E}-101$ \\
PHH_SECRETOME & 211 & 726 & $7.27 \mathrm{E}-101$ \\
TZ_LIVER & 103 & 181 & $3.77 \mathrm{E}-83$ \\
GO_CC_MM_CYTOSOL_Ensembl & 210 & 927 & $3.02 \mathrm{E}-78$ \\
TZ_SCS_MIDPORTALHEP & 81 & 149 & $8.88 \mathrm{E}-63$ \\
GO_MF_MM_ATP_BINDING_EnsembI & 240 & 1454 & $3.22 \mathrm{E}-61$ \\
TZ_MALE_ENRICHED & 113 & 367 & $1.08 \mathrm{E}-55$ \\
GO_BP_MM_METABOLIC_PROCESS_Ensembl & 131 & 521 & $2.05 \mathrm{E}-53$ \\
GO_MF_MM_METAL_ION_BINDING_EEnsembl & 168 & 871 & $1.64 \mathrm{E}-51$ \\
TZ_SCS_MACROPHAGES & 171 & 904 & $2.96 \mathrm{E}-51$ \\
GO_MF_MM_PROTEIN_HOMODIMERIZATION_ACTIVITY_Ensembl & 125 & 509 & $9.79 \mathrm{E}-50$ \\
TZ_SCS_ENDOTHELIALCELLS & 119 & 461 & $9.79 \mathrm{E}-50$ \\
GO_BP_MM_OXIDATION-REDUCTION_PROCESS_Ensembl & 128 & 535 & $1.25 \mathrm{E}-49$ \\
\hline
\end{tabular}


bioRxiv preprint doi: https://doi.org/10.1101/2021.06.18.448955; this version posted June 18, 2021. The copyright holder for this preprint (which was not certified by peer review) is the author/funder, who has granted bioRxiv a license to display the preprint in perpetuity. It is made

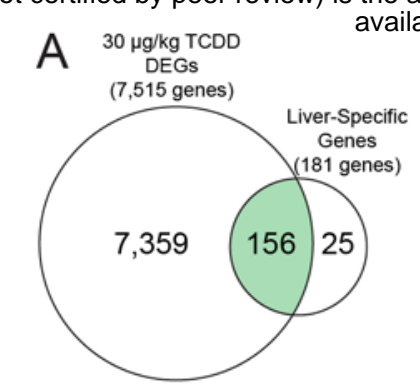

B

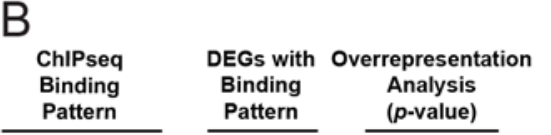

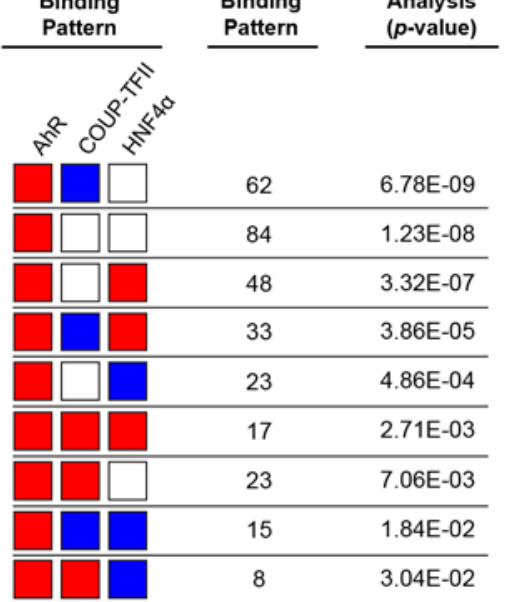

Postive Differentially Enriched Peaks Negative Differentially Enriched Peaks Bound With No Differentially Enriched Peaks

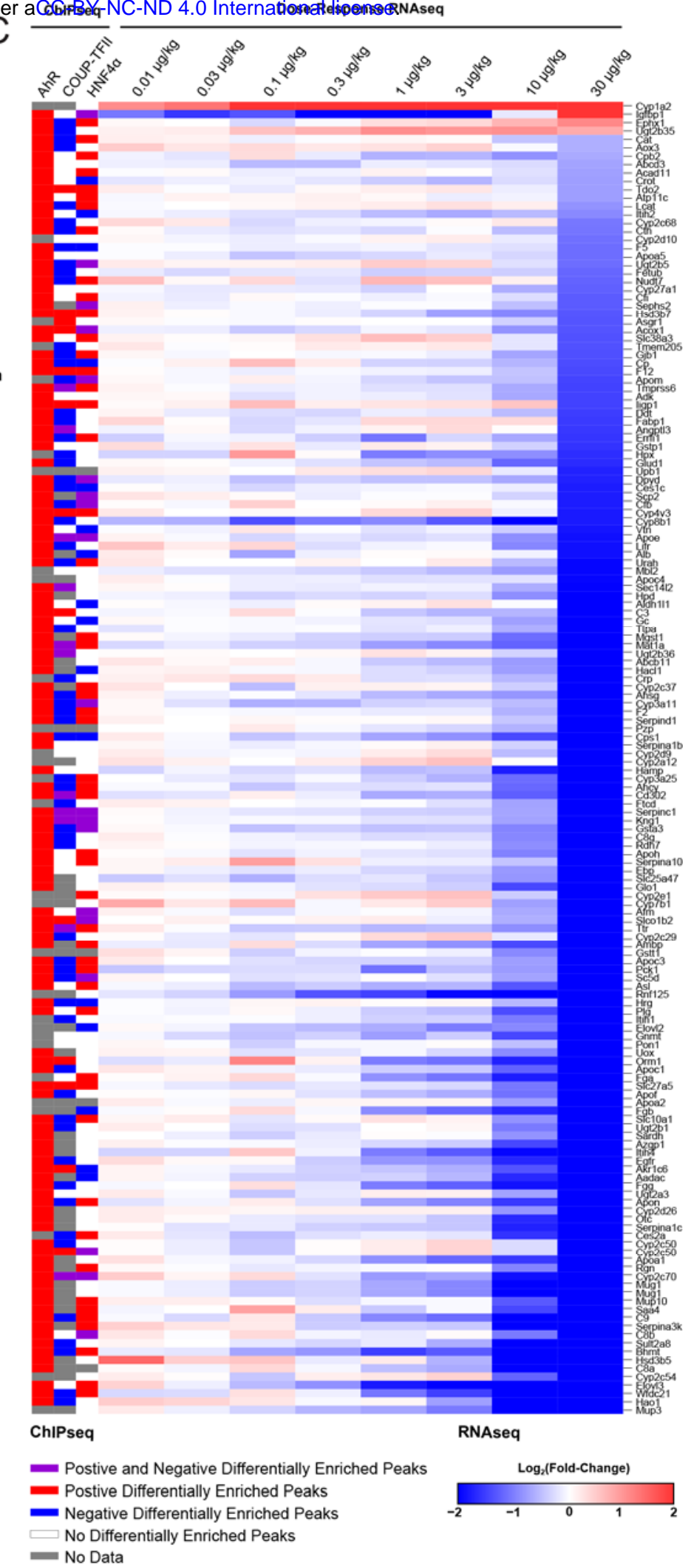

Figure 6: Integration of ChIPseq and dose response RNAseq for liver-specific DEGs. A total of 181 liverspecific genes were identified based on multi-tissue data from BioGPS as reported in Nault et al (Nault et al., 2017). (A) Differential gene expression was assessed for liver-specific genes in mice treated with $30 \mu \mathrm{g} / \mathrm{kg}$ TCDD every 4 days for 28 days. (B) Overrepresentation of transcription factor binding patterns for the 156 liver-specific DEGs was assessed using a one-sided Fisher's exact test with FDR correction. (C) AhR, COUPTFII, and HNF4a binding was mapped to expression of 103 liver-specific DEGs at all doses $(0.01-30 \mu \mathrm{g} / \mathrm{kg})$. Genes are ranked from most induced to most repressed at $30 \mu \mathrm{g} / \mathrm{kg}$. 
bioRxiv preprint doi: https://doi.org/10.1101/2021.06.18.448955; this version posted June 18, 2021. The copyright holder for this preprint (which was not certified by peer review) is the author/funder, who has granted bioRxiv a license to display the preprint in perpetuity. It is made
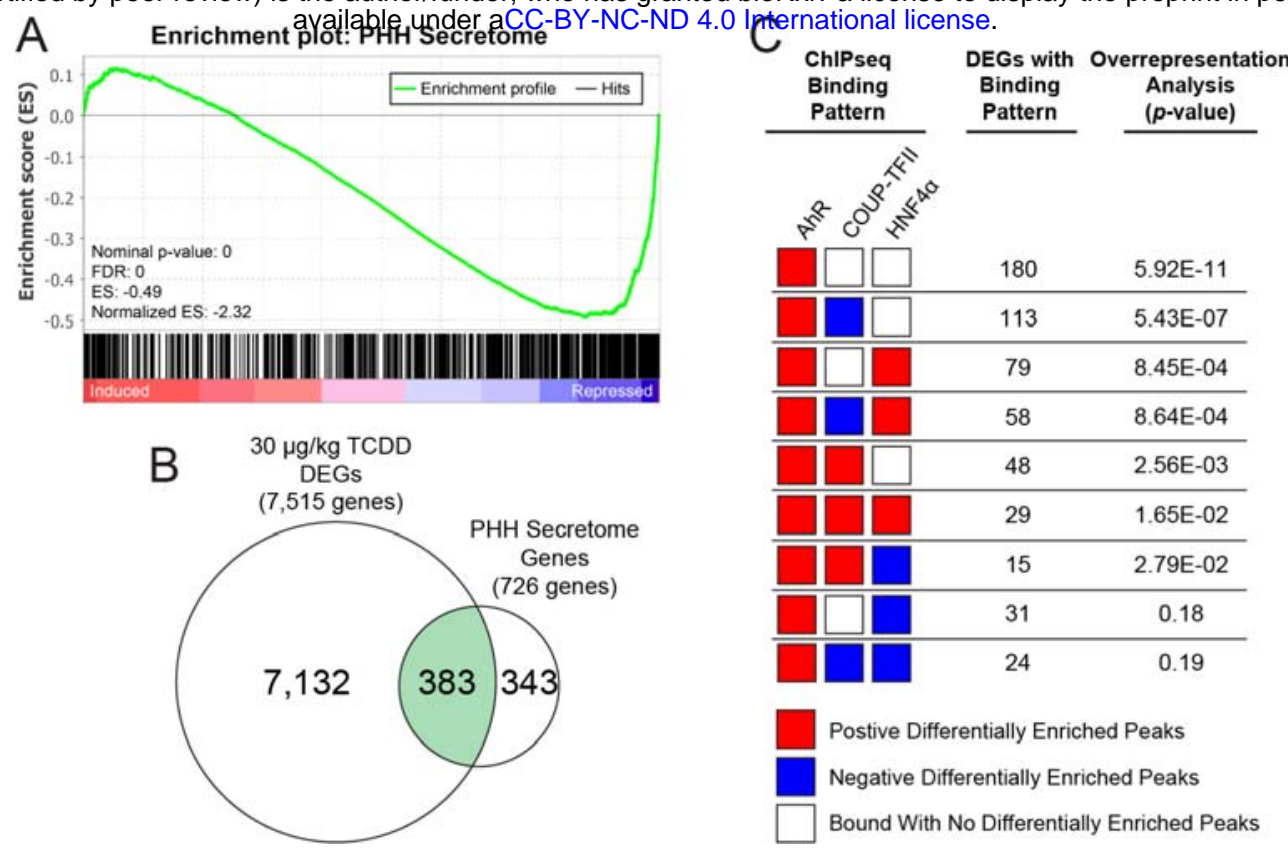

Figure 7: TCDD dose-dependently repressed expression of liver-specific secretome genes. Loss of liver function was assessed by examining changes in hepatic secretome gene expression. A putative primary human hepatocyte $(\mathrm{PHH})$ secretome of 691 genes has been previously reported that was mapped to 726 mouse orthologues (Franko et al., 2019). (A) A gene set enrichment analysis for 726 mouse orthologs of the human $\mathrm{PHH}$ secretome was conducted using data for C57BI/6 male mice orally gavaged with $30 \mathrm{ug} / \mathrm{kg}$ TCDD every 4 days for 28 days. (B) Differential gene expression was assessed for genes encoding the $\mathrm{PHH}$ secretome in mice treated with $30 \mu \mathrm{g} / \mathrm{kg}$ TCDD every 4 days for 28 days. (C) Over-representation of transcription factor binding patterns for the $383 \mathrm{PHH}$ secretome DEGs was assessed using a one-sided Fisher's exact test with FDR correction. 
bioRxiv preprint doi: https://doi.org/10.1101/2021.06.18.448955; this version posted June 18, 2021. The copyright holder for this preprint (which was not certified by peer review) is the author/funder, who has granted bioRxiv a license to display the preprint in perpetuity. It is made
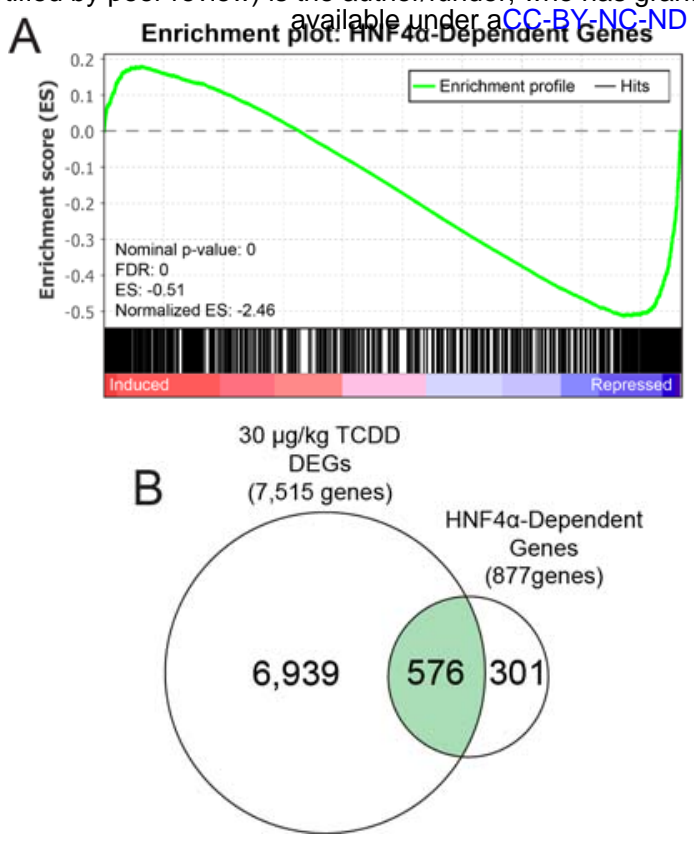

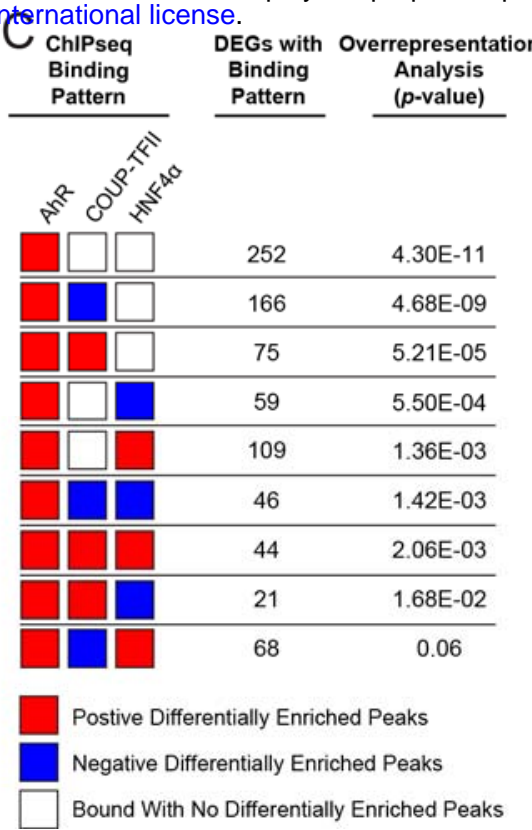

Figure 8: TCDD dose-dependently represses expression of HNF4a-dependent gene expression in the liver. Loss-of-liver function was assessed by examining changes in HNF4a-dependent gene expression. Putative hepatic HNF4a-dependent genes were previously identified (Walesky et al., 2013). (A) Gene set enrichment analysis for HNF4a-dependent genes was conducted using data for C57BI/6 male mice orally gavaged with $30 \mathrm{ug} / \mathrm{kg}$ TCDD every 4 days for 28 days. (B) Differential expression was assessed for HNF4adependent genes in mice treated with $30 \mu \mathrm{g} / \mathrm{kg}$ TCDD every 4 days for 28 days. (C) Over-representation of transcription factor binding patterns for the 576 hepatic HNF4a-dependent DEGs was assessed using a onesided Fisher's exact test with FDR correction. 